\title{
DESCRIPTION OF THE MALE OF HYPOGNATHA BELEM (ARANEAE, ARANEIDAE)
}

\author{
Adalberto J. Santos ${ }^{1,2}$
}

\begin{abstract}
The male of Hypognatha belem Levi, 1996 is described and illustrated for the first time. New records expand the distribution range of the species to northeastern and southeastern Brazil.

KEYWORDS. Hypognatha, Araneidae, Neotropical, Taxonomy.

\section{INTRODUCTION}

The spider genus Hypognatha Guérin-Méneville, 1840 was recently revised by LEVI (1996) and comprises thirty-eight species, of which fifteen have unknown males. Many species are known only from few records. Hypognatha belem Levi, 1996, is an example, besides the female holotype from Belém, State of Pará, Brazil, the species was known until now only by other female from an uncertain locality (probably Amazonas state, Brazil, see LEVI 1996:115). Recently, males and females of this species were collected in spider species richness inventories in northeastern and southeastern Brazil. These new records of $H$. belem illustrates the situation of several neotropical spider species, that probably has large distribution ranges, but due to collection deficiencies, are known from few distant localities. The male of $H$. belem is described and illustrated for the first time.

The material examined was deposited in the collection of Instituto Butantan, São Paulo (IBSP, curator A. D. Brescovit). The format of the description follows that of LEVI (1996), with few modifications. The carapace width was measured at the widest point of thoraxic region. All measurements are in millimeters.
\end{abstract}

\section{Hypognatha belem Levi}

(Figs. 1-4)

Hypognatha belem Levi 1996: 115, 116, figs. 131-133, map 2N (female holotype from Belém, Pará, Brazil, VII.1972, D. G. McGrath, in Museu de Ciências Naturais, Fundação Zoobotânica do Rio Grande do Sul, Porto Alegre (MCN 27010, ex- MCZ, Museum of Comparative Zoology), not examined.

1.Laboratório de Artrópodes, Instituto Butantan. Av. Vital Brasil 1500, 05503-900, São Paulo, São Paulo, Brasil. (oxyopes@yahoo.com) 2.Pós-graduação em Zoologia, Universidade de São Paulo. 


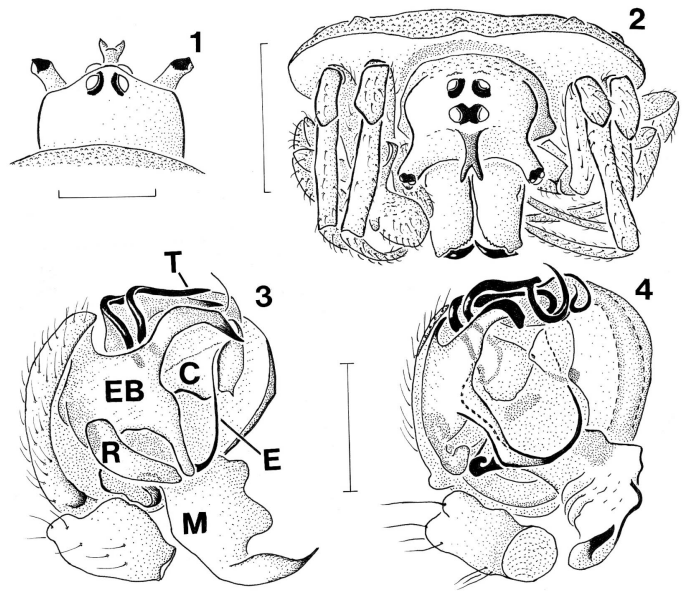

Figs. 1-4. Hypognatha belem Levi, male: 1, carapace, dorsal view; 2, body, frontal view (left palpus removed); 3, palpus, mesal view; 4, ventral view. Abbreviations: C, conductor; E, embolus ; EB, embolus base; M, median apophysis; R, radix; T, terminal apophysis. Scale lines: fig. 1: $0.5 \mathrm{~mm}$; fig. 2: $1.0 \mathrm{~mm}$; figs. $3,4: 0.25 \mathrm{~mm}$.

Diagnosis. Hypognatha belem males are similar to H. matisia Levi (Levi 1996, figs. $123,124)$ by the shape of the bifid median projection of the clypeus (figs. 1,2), but differs by the sinuous ventral margin of the median apophysis, by the large anterior process of the base of embolus, and the terminal apophysis with three coiling filiform extensions (figs. 3, 4).

Description: carapace, chelicerae, labium, and endites red. Sternum red with dark spots. Legs orange, metatarsi and tarsi darker. Dorsum of abdomen gray with black and white small spots. Venter gray with transversal dark spots. Spinnerets brown, darker basally. Total length 2.65; carapace 1.35 long, 0.9 wide. Patella +tibia I length 1.3, II - 1.2, III - 0.7, IV - 0.9 . Abdomen 2.25 long, 2.45 wide. Lateral eyes in lateral projections. Clypeus with a median, bifid process. Cymbium with a small basal, mesal tubercle. Median apophysis pointed and curved in the apex. Embolus long, curved and filiform, arising from an enlarged base.

Material examined. BRAZIL, Bahia: Porto Seguro (Estação Ecológica Pau Brasil), †, 19.IV.1998, A. D. Brescovit (IBSP 17612); Una (Reserva Biológica do Una), ₹, 14.IV.1998, A. D. Brescovit (IBSP 18190); O', XI.2000, A. D. Brescovit et al. (IBSP 28954); Espírito Santo: São Mateus (Reserva Florestal da Companhia Vale do Rio Doce),,+ 2 imm., 19-25.VII.1997, A. D. Brescovit et al. (IBSP 12825); 오 (IBSP 12861); o’, ㅇ (IBSP 26217).

Acknowledgments. To Antonio D. Brescovit and Cristina A. Rheims (IBSP) and two anonymous reviewers for reading and criticizing the manuscript and Angela M. F. Pacheco for helpful suggestions on the illustrations. The staff of the Reserva Florestal da Companhia Vale do Rio Doce and the RestaUNA/PROBIO/PRONABIO project provided support in field work. This study was financed by a FAPESP doctoral fellowship grant (Proc. 99/05659-8).

\section{REFERENCE}

Levi, H. W. 1996. The American orb-weavers Hypognatha, Encyosaccus, Xylethrus, Gasteracantha, and Enacrosoma (Araneae, Araneidae). Bull. Mus. comp. Zool., Cambridge, 155(3):89-157.

Recebido em 21.08.2001; aceito em 21.01.2002. 